\title{
To assess iron deficiency anaemia in patients with cyanotic heart disease compared to general population
}

\author{
Soni S. ${ }^{1}$, Chaudhary P. ${ }^{2}$, Arya S. ${ }^{3}$, Thora S. ${ }^{4}$ \\ ${ }^{1}$ Dr. Sumeet Soni, Senior, Resident, ${ }^{2}$ Dr. Prachi Chaudhary, Assistant Professor, ${ }^{3}$ Dr. Sunil Arya, Assistant Professor, \\ ${ }^{4}$ Dr. S. Thora, Professor and HOD, all authors are affiliated with Department of Pediatrics, M.G.M. Medical College and \\ Associated MY Hospital, Indore, MP, India.
}

Corresponding Author: Dr. Sumeet Soni, 236, Saket Nagar, Indore. Email: sumeets1987@gmail.com

\begin{abstract}
Objective: Congenital heart disease has an overall incidence of 8 per 1000 live births. It can be grouped into acyanotic congenital heart diseases (without a shunt or with a left to right shunt) and cyanotic congenital heart disease (with a right to left shunt). Cyanotic congenital heart diseases are those inborn lesions of the heart and great vessels in which there is shunting of blood from right side of the heart to the left side with the result that de-oxygenated blood enters the systemic circulation, thereby decreasing its oxygen saturation and causing cyanosis. The commonest of these diseases is Tetralogy of Fallot's. Only a few of these diseases are compatible with life beyond 12 years of age. Methods: The present study was carried out in the department of Pediatrics, Mahatma Gandhi Memorial Medical College, Indore from January 2012 to July 2013 (duration of study was one and half years). During this period thirty children with congenital cyanotic heart disease between 6 months to 5 years of age were included in this study. Blood parameters assessed were Hemoglobin (Hb gm\%), Mean Corpuscular Volume (MCV) fl and Ferritin levels. Results: The mean hemoglobin in cyanotic heart disease cases was $13.39 \mathrm{gm} / \mathrm{dl}$ with a S.D. of 2.38. In the control group the mean hemoglobin was $9.57 \mathrm{gm} / \mathrm{dl}$ with a S.D. of 1.29. Mean MCV in cyanotic heart disease cases was $71.47 \mathrm{fl}$ with S.D. of 9.28 and in controls it was $78.41 \mathrm{fl}$ with a S.D. of 5.87. Mean Ferritin in cases was $41.63 \mathrm{ng} / \mathrm{ml}$ with S.D. of 35.04 and in controls it was $78.75 \mathrm{ng} / \mathrm{ml} \mathrm{with} \mathrm{S.D.} \mathrm{of}$ 51.40. $\mathrm{P}$ value was 0.001 indicating a statistically significant decreased ferritin in cases. Conclusion: Iron deficiency anemia was present in $56.6 \%$ of the cases on basis of MCV. The high iron requirements of cyanotic heart disease cases due to increased erythrocytosis induces iron deficiency anemia.There was statistically significant difference in $\mathrm{Hb}$ and MCV values between cases and controls. The ferritin level was statistically significantly lower between cases and controls suggesting iron deficient state in CCHD patients. Iron therapy in iron deficient CCHD (based on hematological and iron indices) patients might improve clinical outcome in these patients.
\end{abstract}

Key words: Congenital heart disease, cyanotic congenital, acyanotic congenital

\section{Introduction}

Congenital heart disease has an overall incidence of 8 per 1000 live births (Nelson,)[1]. It can be grouped into acyanotic congenital heart diseases (without a shunt or with a left to right shunt) and cyanotic congenital heart disease (with a right to left shunt).

Cyanotic congenital heart diseases are those inborn lesions of the heart and great vessels in which there is shunting of blood from right side of the heart to the left side with the result that de-oxygenated blood enters the systemic circulation, thereby decreasing its oxygen saturation and causing cyanosis [1]. The commonest of

Manuscript received: $26^{\text {th }}$ February 2018

Reviewed: $7^{\text {th }}$ March 2018

Author Corrected: $14^{\text {th }}$ March 2018

Accepted for Publication: $17^{\text {th }}$ March 2018 these diseases is Tetralogy of Fallot's [2]. Only a few of these diseases are compatible with life beyond 12 years of age. However, with palliative and corrective surgery, the life span of patients with these disorders has been considerably prolonged.

The clinical profile of the various cyanotic congenital heart diseases includes manifestations such as cyanotic spells, exertional dyspnea, growth retardation, repeated chest infections, palpitations, squatting and cardiovascular findings consistent with the heart lesion [1]. Associated secondary polycythemia causes blood hyper viscosity (usually only when the hematocrit is more than 0.65) which causes symptoms such as headache, faintness, dizziness, visual disturbances, fatigue, muscle 


\section{Editorial}

pain, muscle weakness, depressed mentation [3]. Complications such as coagulation abnormalities can cause hemolysis, epistaxis, easy bruising, gingival bleeding, menorrhagia. Arthralgia and acute gouty arthritis can occur due to hyperuricemia which results from decreased renal uric acid clearance [4]. Children are more prone to cerebrovascular accidents [5]. Acute cholecystitis due to calcium bilirubinate stones can also occur [3].

Hypoxia of the renal tissue releases erythropoietin which stimulates the erythroid marrow to become hyperplastic and red cell mass and total blood volume increases [6]. Platelet counts are often moderately reduced but more important is a qualitative platelet hemostatis defect

Upto a point the increase in red cell mass enhances oxygen transport and delivery. But the increased number of red cells also cause a rise in the packed cell volume (hematocrit) thereby increasing the whole blood viscosity, which if excessive, affects blood flow and, therefore tissue perfusion. In cases in which blood hyper viscosity itself starts causing symptoms of decreased tissue blood flow, phlebotomy becomes a therapeutic necessity [3]. Polycythemic patients often get rapid relief of symptoms from venesection therapy, presumably from lowering of their whole blood viscosity, but later on identical symptoms recur at lower haemoglobin concentrations in patients who have been made severely iron deficient (thereby causing hypochromic microcytic anaemia) following repeated vene sections [7] and other causes of iron deficiency.

It is believed that the combination of the high red cell mass and known decreased deformability of iron deficient red blood cells [8] may lead to a "secondary hyper-viscosity syndrome" in these patients.

The hyper viscosity symptoms of iron deficiency and polycythemia induced hyper viscosity are indistinguishable clinically. But if hyper viscosity symptoms are present with hematocrit levels less than 0.65 iron deficiency should be suspected as the cause and phlebotomy under these circumstances aggravates the symptoms.

\section{Materials and Methods}

Place of study: Department of Pediatrics, Mahatma Gandhi Memorial Medical College, Indore from January 2012 to July 2013 (duration of study was one and half years).

Type of study: Observational study

Inclusion criteria: Congenital cyanotic heart disease between 6 months to 5 years of age were included in this study.

Investigations done: Blood parameters assessed were Hemoglobin ( $\mathrm{Hb}$ gm \%), Mean Corpuscular Volume (MCV) fl and Ferritin levels.

Exclusion criteria: Children not having CCHD

\section{Measurement of ferritin:}

\section{Ferritin}

\begin{tabular}{|c|c|}
\hline Age (Years) & Ferritin Level (NG/ML) \\
\hline$<5$ years & $>12$ \\
\hline$>5$ years & $>15$ \\
\hline
\end{tabular}

\section{Result}

Table- 1: Hemoglobin in Cases and Controls.

\begin{tabular}{|c|c|c|}
\hline Hemoglobin \% & Cases & Controls \\
\hline$>15$ & 6 & 0 \\
\hline 11 TO 15 & 21 & 13 \\
\hline$<11$ & 3 & 17 \\
\hline
\end{tabular}

The mean hemoglobin in cyanotic heart disease cases was $13.39 \mathrm{gm} / \mathrm{dl}$ with a S.D. of 2.38 . In the control group the mean hemoglobin was $9.57 \mathrm{gm} / \mathrm{dl}$ with a S.D. of 1.29. The t value was 7.7 and p value was 0.034 indicating a statistically significant increased hemoglobin levels in cyanotic heart disease cases. 
Editorial

Table- 2: Mean Corpuscular Volume in Cases and Controls.

\begin{tabular}{|c|c|c|}
\hline & $<\mathbf{7 5}$ & $>\mathbf{7 5}$ \\
\hline Cases & 11 & 19 \\
\hline Controls & 5 & 25 \\
\hline
\end{tabular}

Mean MCV in cyanotic heart disease cases was $71.47 \mathrm{fl}$ with S.D. of 9.28 and in controls it was $78.41 \mathrm{fl}$ with a S.D. of 5.87. The $t$ value was -3.45 and $p$ value was 0.01 showing a statistically significant decreased MCV in cyanotic heart disease cases.

Table- 3: Ferritin in cases and controls.

\begin{tabular}{|c|c|c|c|}
\hline & $<7$ & 7 to 30 & $30-142$ \\
\hline Cases & 7 & 7 & 16 \\
\hline Controls & 3 & 6 & 21 \\
\hline
\end{tabular}

- 23 percent of cases had ferritin less than $7 \mathrm{ng} / \mathrm{ml}$ against 10 percent of controls suggesting severe iron deficiency.

- 23 percent of cases had ferritin between $7 \mathrm{ng} / \mathrm{ml}$ and $30 \mathrm{ng} / \mathrm{ml}$ against 20 percent of controls suggesting mild to moderate iron deficiency.

Mean Ferritin in cases was $41.63 \mathrm{ng} / \mathrm{ml}$ with S.D. of 35.04 and in controls it was $78.75 \mathrm{ng} / \mathrm{ml}$ with S.D. of 51.40. The $\mathrm{t}$ value was -3.26 and p value was 0.001 indicating a statistically significant decreased ferritin in cases.

\section{Discussion}

Maximum number of patients (70\% of cases) belonged to age group between 6 months to 1 year. $17 \%$ belonged to age group 13 months to 24 months. $13 \%$ belonged to age group 25 months to 60 months.

Lango et al [16] found male female ratio in his study on cyanotic heart disease patients to be 52:48. 50\% cases were from rural areas and 50\% from urban areas. 37\% of total cases were females below 1 year of age. $33 \%$ of total cases were males below 1 year of age. $80 \%$ of cases between 1 to 2 years of age were females. Between 2 to 5 years of age $100 \%$ of cases were males.

The mean hemoglobin in cyanotic heart disease cases was $13.39 \mathrm{gm} / \mathrm{dl}$ with a S.D. of 2.38. In the control group the mean hemoglobin was $9.57 \mathrm{gm} / \mathrm{dl}$ with a S.D. of 1.29. Pvalue was 0.034 indicating a statistically significant increased hemoglobin levels in cyanotic heart disease cases.

Koeffler and Gold Wasser [9] and Erslev and Karo [10] observed renal hypoxia causes erythropoietin release which stimulates the erythroid marrow to become hyperplastic thereby raising the red cell mass [6].

Jha et al [11] in Central India found mean hemoglobin in cyanotic heart disease cases to be $11.0 \mathrm{gm} \%$. Cemile et al (1999) [12] in Ankara, Turkey found mean hemoglobin to be $14.8 \mathrm{gm} \%$. MAmoozgar [13] Iran found mean hemoglobin in cyanotic heart disease patients to be $16.0 \mathrm{gm} \%$. OO Ogunkule [14] in his study in Nigeria found mean hemoglobin to be $17.0 \mathrm{gm} \%$

Mean MCV in cyanotic heart disease cases was $71.47 \mathrm{fl}$ with S.D. of 9.28 and in controls it was $78.41 \mathrm{fl}$ with a S.D. of 5.87. P value was 0.01 showing a statistically significant decreased MCV in cyanotic heart disease cases. Jha et al [11] in Central India found mean MCV value in cyanotic congenital heart disease to be $76.4 \mathrm{fl}$. M Amoozgar [13], Iran found mean corpuscular volume in cyanotic heart disease patients to be $73.8 \mathrm{fl}$ OO Ogunkule [14] in his study in Nigeria found mean corpuscular volume to be $80.7 \mathrm{fl}$.

Cemile et al [12] in Ankara, Turkey found mean corpuscular volume to be $77.5 \mathrm{fl}$. Olcay et al [15] in Turkey in his study to compare hematological parameters between iron sufficient and iron deficient cyanotic heart disease patients found mean MCV to be $83.2 \mathrm{fl}$ in iron sufficient group and $64.9 \mathrm{fl}$ in iron deficient group.

Mean Ferritin in cases was $41.63 \mathrm{ng} / \mathrm{ml}$ with S.D. of 35.04 and in controls it was $78.75 \mathrm{ng} / \mathrm{ml}$ with S.D. of 51.40. $\mathrm{P}$ value was 0.001 indicating a statistically significant decreased ferritin in cases. 


\section{Editorial}

Olcay et al [15] in Turkey in his study to compare hematological parameters between iron sufficient and iron deficient cyanotic heart disease patients found mean Ferritin to be $37.2 \mathrm{ng} / \mathrm{ml}$ in iron sufficient group and $7.5 \mathrm{ng} / \mathrm{ml}$ in iron deficient group. Cemile et al [12] in Ankara, Turkey found mean Ferritin to be 39.2 $\mathrm{ng} / \mathrm{ml}$. Lango [16] in Kenya found mean Ferritin to be $48.9 \mathrm{ng} / \mathrm{ml}$.

This study stresses on the fact that iron deficiency anemia is a relative iron deficiency state. Hemoglobin may be normal but red blood cells are microcytic hypochromic in nature which suggests iron deficiency anemia. This could be further confirmed by ferritin levels which are relatively low than general population.

The use of iron therapy in children with cyanotic heart disease will alleviate iron deficiency symptoms and will improve overall well being in these patients. Recommended dose of iron is $3-5 \mathrm{mg} / \mathrm{kg} /$ day.

\section{Conclusion}

Iron deficiency anemia was present in $56.6 \%$ of the cases on basis of MCV. The high iron requirements of cyanotic heart disease cases due to increased erythrocytosis induces iron deficiency anemia. There was statistically significant difference in $\mathrm{Hb}$ and $\mathrm{MCV}$ values between cases and controls. The ferritin level was statistically significantly lower between cases and controls suggesting iron deficient state in CCHD patients. Iron therapy in iron deficient CCHD (based on hematological and iron indices) patients might improve clinical outcome in these patients.

\section{Recommendations}

The ferritin level was statistically significantly lower between cases and controls suggesting iron deficient state in CCHD patients. Iron therapy in iron deficient CCHD (based on hematological and iron indices) patients might improve clinical outcome in these patients.

Blood parameters should be regularly monitored in cyanotic congenital heart disease patients.

Proper feeding, treatment of paristitic infections, timely weaning are other contributing factors for anemia and iron deficiency states as in general population which too should be given utmost priority.

Source of funding: none, in house investigatory facilities were used and outsourcing was utilized as per the institutional norms.
Funding: Nil, Conflict of interest: None initiated, Perission from IRB: Yes

Contribution details: Dr Sharad Thora, Dr Prachi Chaudhary and Dr Sunil Arya had planned, designed, guided the study and analysed the data. Dr Sumeet Soni had collected the data and analysed it.

\section{References}

1. Nelson WE. Congenital heart disease. In: Nelson WE, Behrman RE, Vaughan VC, eds. Nelson Textbook of Pediatrics 13th ed. Philadelphia: W.B. Saunders Co., 2011, Ch.14;962.

2. Keith JD, Rowe RD, Vlad P. Heart Disease in Infancy and Childhood. 3rd ed. New York : Macmillan, 19978, Ch.1.

3. Perloff JK, Rosove MH, Child JS, Wright GB: Adults with cyanotic congenital heart disease: Hematologic management. Ann Intern med 2008; 109: 406-13.

4. Ross EA, Perloff JK, Danovitch GM, Child JS, Canobbio MM. Renal function and urate metabolism in late survivors with cyanotic congenital heart disease. Circulation. 1986 Mar; 73 (3):396-400.

5. Phornphutkul C, Rosenthal A, Nadas AS, Berenberg W. Cerebrovascular accidents in infants and children with cyanotic congenital heart disease. Am J Cardiol 1973; 32:329-34.

6. Scott WS, Elliot SR, Clay RC. Blood volume in cya-notic congenital heart disease; Simultaneous measure-ments with Evans blue and radioactive phosphorus. Bull Johns's Hopkins Hosp 1951; 121-32.

7. Hutton RD. $\mathrm{Br} J$ Haematol. The effect of iron deficiency on whole blood viscosity in polycythaemic patients. 1979 Oct; 43 (2):191-9.

8. Card RT, Weintraub LR. Metabolic abnormalities of erythrocytes in severe iron deficiency.Blood. 1971 Jun; 37 (6):725-32.

9. Koeffler HP, Goldwasser E: Erythropoietin radioimmunoassay in evaluating patients with polycythemia. Ann Intern Med 1981; 94:44-7.

10. Erslev AJ, Caro J. Pure erythrocytosis classified according to erythropoietin titers. Am J Med. 1984 Jan; 76 (1):57-61. 


\section{Editorial}

11. Jha A: A study of assessment of iron deficiency anemia in children with CCHD.1997

12. Cemile Banu Onur, Tansul Sipahi, Betul Tavir, Selmin Karademir, Aysel Yoney. Diagnosing Iron deficiency in cyanotic heart disease. Indian J Pediatric 2003; 70 (1):29 -31

13. H Amoozgar, M Soltani, A Besharati, S Cheriki. Undiagnosed anemia in pediatric patient with congenital heart disease. Iran Cardiovasc Res J 2011; 5 (2): 69-70.
14. OO Ogunkule: Parameters of iron Deficiency in CCHD. Nigeria. 2012. Journal 34 (2 );12-15

15. L Olcay, S. Ozer, A Gurgey, M Saralcar, S Ozme, A Bilgic, S Ozkutlu, A Celikar. Parameters of iron deficiency anemia in children with cyanotic heart disease New York Inc.1996

16. Lang'o MO, Githanga JN, Yuko-Jowi CA. Prevalence of iron deficiency in children with cyanotic heart disease seen at Kenyatta National Hospital and Mater Hospital Nairobi. East Afr Med J. 2009 Dec; 86 (12 Suppl): S47-51.

\section{How to cite this article?}

Soni S, Chaudhary P, Arya S, Thora S. To assess iron deficiency anaemia in patients with cyanotic heart disease compared to general population. Int J Pediatr Res. 2018;5(5):268-272.doi:10.17511/ijpr.2018.i05.05. 